\title{
Animal Farm Is a World of Man
}

\section{Rania Khelifa Chelihi ${ }^{1}$, Mohd Nazri Latiff Azmí1, and Hardev Kaur²}

${ }^{1}$ Universiti Sultan Zainal Abidin(UNISZA), Kuala Terengganu 21300, Malaysia

${ }^{2}$ Universiti Putra Malaysia (UPM), Serdang 43400, Malaysia

\section{Abstract}

In the beginning of the 20th century, feminist literary theory was concerned mainly with the social and political role of women, as well as women's role in literature. In the second half of the century, it is tried to study women's social positions and their rights compared to the male counterpart. One of the most explored themes since then was gender and patriarchy. The aim of this paper is to show how women were depicted in literature after half a century of the struggle of the first wave feminist towards equality and stress the importance of theorizing the concept of patriarchy, as a first step to understanding women's subjugation. This unfolds through a re-visitation of George Orwell's fiction novels. Orwell is better known by his political writing. Although he has never used the word "Feminism", in any of his fictional works, two decades

Corresponding Author: Rania Khelifa Chelihi rania.shelihi@gmail.com

Received: 1 July 2019

Accepted: 18 July 2019

Published: 31 July 2019

Publishing services provided by Knowledge

(c) Rania Khelifa Chelihi et al. This article is distributed under the terms of the Commons Attribution License, which permits unrestricted use and redistribution provided that the original author and source are credited.

Selection and Peer-review under the responsibility of the AICLL 2019 Conference Committee. after his death, the radical feminist, Daphne Patai accused him that he is anti-feminist, fundamentally because of his deprecatory stands towards women through his female characters. The selected texts reinforce patriarchal ideology, through the way Orwell portrayed his male and female characters. A feminist analytical approach will be adopted in the realization of this research, in order to analyse the novel in depth, with a focus on Orwell's portrayal of female characters. Observing and commenting how he debases, mistreats and degrades them. Further, it sheds the light on how he portrays his male characters by analysing female and male protagonists. The significant of the study is to show the social and political context of the time regarding the role and the identity of women in the British society in the 20th century, and how women were treated under patriarch society and still until our days. Moreover, it sheds light on how patriarchy the concept of women oppression helped in the development of feminist theories.

Keywords: Patriarchy, oppression, female, feminism, male.

\section{Introduction}

Often times it is argued that throughout history women in different cultures were under men's domination in all spheres of life. In a patriarchal system, males are considered as the strongest sex, courageous, intelligent, superior and more rational than females, that God created men to dominate (Sultana, 2012). Women, on the other hand, were considered as incomplete, governed by their emotions, unintelligent, more passive, physically weaker, unstable and rationally inferior. In sum, patriarchy is a system used 
"to refer to male domination, to the power relationships by which men dominate women, and to characterize a system whereby women are kept subordinate in a number of ways" (Bhasin, 2006) such as; subordination discrimination, mental and spiritual violence as well as abuse, physical and oppression. Although the issues of gender "are buried in ancient Greece"(DOREY-STEIN Caroline, 2015), many scholars argue that the twentieth century witnessed a significant change, in gender roles, and the gender issues come to the forefront, and women's war against discrimination, persecution, marginalization and subordination because of their gender, ethnicity, religion and class, and within all aspects of their lives (Mures, 2005). In analyzing feminism, it is clear that feminists communicate a shared emotional experience of women's misery, their feelings of embarrassment, inferiority and the emotional torment inflicted upon them under patriarchy. In fact, through western history, a gloomy and alarming picture of discrimination against women has painted.

Patriarchy, as a concept for female oppression, has been used over time in a variety of ways. During the pre-19th century, feminism in literature was spearheaded by the writings of the British 'Grandmom' of modern feminist writers, Mary Wollstonecraft (17591797), Christine de Pizan in Italy(1365,1430), Olympe de Gouges in France (1748,1797).During the 19th century, The Americans Sojourner Truth (1797,1883), Susan An Barbara Leigh Smith Bodichon (1827-1891), Lydia Ernestine Becker (1827-1890), and Thomas Stearns Eliot (1888-1965), it is also obvious in the writings of the French Simone de Beauvoir (1908-1986), Angélique Arnaud (1799-1884) and the American writers Charlotte Perkins Gilman (1860-1935) and Edith Wharton (1862-1937) among others.

Since literature reflects life, it is natural that those writers reflect their experiences of suffering within a patriarchal society in their writings to express the extreme situations of women's gender struggle against patriarchy. Generally speaking this struggle against patriarchy usually represented humiliation, discrimination, exploitation, violence, control and oppression by men against women in female writings. But in this paper, we will take it from male eyes. The selected novel by George Orwell; The Animal Farm (1945) has the same theme of male domination and female discrimination and marginalization.

It is widely known that George Orwell, the penname of Eric Arthur Blair, was a prophet realm of political writing (Eckstein, 1984), and he is largely applauded for defending the ideology he heartily adhered to social democracy. It is quoted by Patai that Orwell in 1946 declared that "Every line of serious work I have written, directly or indirectly, against totalitarianism and for democratic socialism, as I understand it" (1984). In this respect, during his time and at least two decades after his death, his astute observations on politics confined the interest in his writings and views to the political field though 
he literally never used the word "feminism" in any of his fictional or nonfictional or journalistic works, George Orwell seemed to have a tinge of unusual attitude when it comes to women (Ekstein, 1984). It was not until the year 1984, when Daphne Patai, a feminist scholar and languages teacher at the University of Massachusetts at Amherst, "...her radical feminism has led her to insight about Orwell which is of the greatest value: his obsession with masculinity of the most traditional, Hemingway- esque type" (Ekstein, 1984). The central research question that this study aims to answer: Is George Orwell anti-feminist and he is obsessed with masculinity as stated by Patai? Or trying to regenerate what the social order used to be primarily during the Victorian era?

\section{Literature Review}

This study will be as a whole, a feminist one. The study proposes to look into the Animal Farm novel, in order to analyze it in depth with a focus on the portrayal of female characters, observing and commenting how he debases, mistreats and degrades them, how he gives them trivial and minor roles in the plot and above all, how he mars their images. Moreover, the study will shed the light on how Orwell portrays his male characters and prototypes, by analyzing protagonist male characters in the selected text. In his nonfiction, Orwell treats and sees the female character from a realistic perspective, so, he actually depicts women in a direct and explicit manner. In addition, the author's social and political convictions could widely interfere in the shaping of his view on non-fictional characterization of females and could be based on his morals rather than emotions. Whereas, his fictional works are more subtle about the matter since they deal with the characters of his own imagination so they are more subtly described and tell more about how he subconsciously sees and treats women and may also provide with what could a female's position in Orwell's life or social order truly be. Since this is not a comparative study, the research, in general, follows female and male developments and actions using patriarchy concept as an analytical tool.

\subsection{Patriarchy}

Feminists, throughout history, have brought attention to the issue of patriarchy and its negative effects on women. The term patriarchy is difficult to explain, as its meanings are both various and contested in feminists discourse. The word patriarchy derives from the Greek words patér 'father' and arché 'rule' (Mounce, 1994), and it literally means the rule of the patriarch in "a male-dominated family". This specific type of family refers to 
the large household of the patriarch who is under the rule of this dominant male; women, young men, children... etc. It is a system in which women are treated as inferior in all aspects of life and experience all kinds of oppression, exploitation and subordination by men. Now the concept of patriarchy is defined more generally as "male domination, to the power relationships by which men dominate women, and to characterize a system whereby women are kept subordinate in a number of ways (Bhasin, 2006). According to the feminists Ray (2011) and Walby (1990), patriarchy is a system of social structures and practices in which women are ruled, exploited and abused by men, they define patriarchy as a system because this helps us to dismiss the notion of biological determinism. Walaby identifies six structures of patriarchy and explains that it is defined in terms of the social relationship in each structure, they are:

...a patriarchal mode of production in which women's labour

is expropriated by their husbands; patriarchal relations with

waged labour; the patriarchal state; male violence; patriarchal

relations in sexuality and patriarchal culture (Walby, 1990).

Walby further develops her patriarchy's definition by making a distinction between private and public patriarchy. She defines private patriarchy as "a system based upon household production as the main site of women's oppression. Public patriarchy is based principally in public sites such as employment and the state. The household does not cease to be a patriarchal form, but it is no longer the chief state in private patriarchy. The expropriation of women's labour takes place primarily by individual patriarchs within the household, while in public form it is more collective appropriation" (Walby, 1990).

Patriarchy, as stated by some feminists, is a concept which refers to the preservation of the society's hegemonic structure whether it is related to its capitalistic underpinnings or structure.While other feminists see it as an explicit issue that is linked directly to gender inequity (Bryson, 2003; POLLERT, 1996; Sylvia Walby, 1990). Jones (2000) defines patriarchy as the "rule of men over women". Moreover, it indicates a grid of economic, political, religious and social regulations which supported men domination over women throughout history. The definition of patriarchy as stated by Walby is differed from the perspectives of Marxist and Radical feminists, mainly in the idea that gender inequality, whether it is derived from capitalism or it is an independent system of patriarchy. Radical feminists by analyzing gender inequality, they find that patriarchy "does not derive from any other system of social inequality, for instance, it is not a by-product of capitalism", a system that co-exists alongside capitalism. They pay more attention to how male dominates female. While Marxist feminists definitions 
differ, especially in terms of considering gender inequality as not an independent system which is derived from capitalism and does not have any relation to other social inequality systems. It is legitimately attached to modes of production ( Jackson, 1998; Walby, 1990). Walby (1990) explained that patriarchy is an empty or neutral category, yet provides a permanent reminder that men, as opposed to women, are the overwhelming and structurally privileged group.

\section{Discussion}

\subsection{Men are superior in A.F}

Animal Farm is a novel written by George Orwell. The novel takes place in England, in a yard which is named "Animal Farm", it was published in 1945. It is considered as one of the best novels in the 20th century and still.It is a story about the "Manor Farm", where animals decided to revolt against the human owner of the farm, who is named Mr. Jones. Simultaneously, there is an animal leader who is called Old major. He is the patriarch pig in the Animal Farm society. After the death of Old Major, other two boars have taken his place as leaders of the farm. In the farm, the reader can notice that male animals held leadership positions and female animals are subordinated and mistreated. Accordingly, one can hypothesize that animals in the novel are assumed proletarian class status; thus, supporting the Marxist thoughts about the alienation of work and the dehumanization of the working class. The fundamental issue of Orwell, when he was writing Animal Farm, satirized the Russian revolution dictatorship, and the world's dictatorship in general, and he does not declaim "the vertical division of society" based on sex, where patriarchy still exists. Although he tries to convey his political message via animal's world instead of human being, he could not overt from "the messy business of the gender hierarchy", that is very clear in the first pages of the novel. It is worth to note that the pigs who deceive the rebellion and who begins it, are boars not only pigs. Entire pigs are kept just for nurture purposes. When old major "the prize middle white boar" (Orwell, 1951,7), asked the other animals for a meeting to tell them about his dream. Orwell depicted him as the dominated male-patriarch- in his society (the farm), he was "twelve years old and had lately grown rather stout, but he was still a majestic looking pig, with a wise and benevolent appearance in spite of the fact that his tushes had never been cut" (Orwell, 1951: 8).

Old Major declares that he is one of the fortuitous pigs, comparing his life with those of the less providential animals in the Manor farm. He added: "I am twelve years old and 
had over four hundred children, such is the natural life of a pig" (Orwell, 1951,12). Orwell in this statement duplicates the scenario of stressing the importance of paternity, we have seen in his other fiction. As though, reproduction is in fact done by male. Power originates from parenthood and phallus. The reader cannot see female pigs (sows), as we are supposed to see them. They appear only in the last chapter of the novel. The patriarch Major passed away before he realizes his dream; the rebellion success. However, like in all patriarchal societies, his leadership position is inherited by the two boars snowball and Napoleon. The two boars are the ones who lead the revolt against Mr. Jones. George Orwell preserves images of masculinity via his depiction of Snowball and Napoleon. The two boars are icons of power. Napoleon was a large, rather fiercelooking Berkshire boar, the only Berkshire on the farm, not much of a talker, but with a reputation for getting his own way (Orwell, 1951: 9). The physical strength made him very powerful. He is portrayed as a tyrant and deceitful. He utilizes the other animals for his personal benefit "he is capable of having his 'comrades' put to death to protect his position" (Orwell, 1951: 19). Comparing to Napoleon, Snowball was a more vivacious pig than Napoleon, quicker in speech and more inventive, but was not considered to have the same depth of character" (Orwell, 1951, 9). His bravery nature, physical strength, and his speaking skills are the substance of his power.

Men are given the opportunity to be a leader more than women in patriarchal societies notwithstanding when women prove that they are more intelligent than men because these societies are interested in gender more than leadership proficiency. The authority is given only to male pigs (Johns, Napoleon and Major), not because of their leadership characteristics, but because the Manor farm world is similar to "a male dominated family", this given type of family refers to "the large household of the patriarch, who is under the rule of his dominant male, women, young men and children...etc " (Bhasin, 2006).

In the novel it is said that "the work of teaching and organizing the others fell naturally upon the pigs, who were generally recognized as being the cleverest of the animal" (Orwell, 1951: 19), the quote shows up that the boars will be the only ones who lead and control the teaching's part. They succeeded in convincing the rest that they are advantageous and they worth it, because "with their superior knowledge it was natural that they should assume the leadership" (Orwell, 1951: 9). But they want them to work diligently for pleasing them -the powerful animals-. It is exactly the same to the situation of women, who are making a huge effort through the feminist movements and struggling for decades, against unequable and hierarchical relationships among women, just to be part of the system, but unfortunately, women throughout history are oppressed and humiliated until now, where some people still treated them as a house object (Wood, 
2013). Actually, like Daphne Patai says: "the pigs would be the sole animals, while most of the other animals are stereotyped females: compliant, hardworking drones brainwashed with the illusion that their work is done for themselves, surrendering the fruits of their productive and reproductive labour to their masters, who tell them that there never was hope of a different future" (Patai, 1984).

Along these lines, as in most of the power connections among females and males, the boars are the farm's brain workers, and the rest of the animals are nothing without them. Thus, they require and want bigger portions. They expect the industrious work, the surveillance on the farm's economy and the political life. Thus, the rest (females) are less significant, they could not pay attention to the entire farm (home).

\subsection{Women are subordinated in A.F}

Female characters in Animal Farm are not completely developed in their characterisation. Female animals are encountering various problems in the farm. Some of them are being under male animals harassment caused by their personal appearance. A lot of female animals are unaccepted by others in the farm. Therefore, in Animal Farm, men act as the leaders who control most of the power, but women get exploited and marginalized.

Mollie is one of the female characters in the novel. Though Mollie in the fable appeared as pretty and beautiful mare, she is still considered as all women in patriarch societies: incomplete, governed by their emotions, more passive, physically weaker, unstable, unintelligent and rationally inferior (Eisenstein, 1984). From the very first pages of the fable, George Orwell described Mollie as a stupid mare, who came late to the speech of Old Major, and she opted " a place near the front and began flirting her white mane, hoping to draw attention to the red ribbons it was plaited with" (Orwell, 1951: 9). Moreover, she is described as illiterate and she refuses "to learn any but the five letters that spell her name. She would form these very neatly out of pieces of twig and would decorate them with a flower or two and walk around admiring them" (Orwell, 1951: 37).

As women are deemed that they are governed by their emotions, Mollie's first and last concern was to know if they would offer her sugar and if she would be permitted to wear ribbons after the revolt, whereas, the other animals were listening carefully to the speech and thinking how they could put an end of the oppression they suffered, and how they could direct the farming operations themselves. Moreover, she is a trivial and an indolent mare, she betrayed her comrades and quit the farm with humans, after she was seduced by more sugar and ribbons. 
It was the first time in all his writing, George Orwell turned the light on the importance of female production in societies. In his speech, Old Major asks the hens to give up their eggs to destroy Mr. Jones economically. He said "you hens, how many eggs have you laid this last year, and how many of those eggs ever hatched into chickens? The rest have all gone to market to bring in money for Jones and his men".

Though they still do their part on the farm and they play a crucial role in increasing the farm's economics, they are still described as "the stupider animals" in the farm who were not able to learn the seven amendments by heart. From the beginning, the hens encountered some problems in the farm. For example, when they ask for milk as Mr. Jones used to give them. Napoleon asked them to forget about the milk. The pigs are the sole animals who are utilizing it for themselves, and they convince the other animals that they merit milk and apple, because they are the farm's brains.

It is exactly the same situation of men and women relationships in all patriarchal societies. Men are categorized as having the following characteristics: Power, force, virile courage, vigor, self-confidence and the capacity to deal with the outside world. These characteristics were reflected in the sorts of work that men occupied. Men were in charge of all what is considered as "heavy labor". (Aweda, 1984; Bernard, 1981; Carrigan, Connell, \& Lee, 1987), women oversee the domestic chores. They kept houses, processed and cooked all foods. They also help in the planting and harvesting of food crops and cash crops. They were primarily responsible for the bearing and rearing of children from birth on; men were only called upon to assist when extraordinary discipline was considered necessary especially for the boys (Aweda, 1984).

The hens are disproportionately exploited by Napoleon because of their reproductive ability. As human females are exploited by human males who are in positions of power (Brown, 2016). At the point when the hens discover that the pigs are selling the eggs to humans as Mr. Jones did. "When the hens heard, they raised a terrible outcry" (Orwell, 1951,79), they start dropping the eggs and "smashed [it] to pieces on the floor"(Orwell,1951,79). The consequences of the rebellion of the hens were considered as a negative way. All the hens are starved and put them in prison. Moreover, Napoleon ordered the dogs to kill all the hens who refuse to obey his orders.

\section{Conclusion}

Although Orwell was focusing on political issues in his writing, defending his ideology on social democracy and he did not care for women's issues and feminists movement in particular. Yet, his female characters in his fiction still depicted lower class citizens 
and they are naturally inferior compared to their male equivalents. Even in the cases when women break a rule, their characters are still not appropriately developed, such as Molly the mare and the cat in Animal Farm.

To conclude, men are constantly selected as the leaders and gain all of the power in the farm, whereas women are exploited from that authority and power. Thus, the feminist analysis of the novel in this paper reveals that the stereotypical notions patriarchy indeed exists in Orwell's political novel, Animal Farm.

\section{Acknowledgements}

Authors would like to express our deepest gratitude to the committee of the Proceedings of the $2^{\text {nd }}$ Annual International Conference on Language and Literature, 2019, Fakultas Sastra, UISU, Medan, Indonesia, who gave me the chance to present my paper and enrich my knowledge.

\section{References}

[1] Aweda, A. D. (1984). Sex-role inequalities in the African family: Contemporary implications. Ife Social Sciences Review, 7(1), 188-197.

[2] Bernard, J. (1981). The good-provider role: Its rise and fall. American Psychologist, 36(1), 1.

[3] Bhasin, kamla. (2006). what is patriarchy:women unlimited. In New delhi.

[4] Brown, K. (2016). A Feminist Analysis of Human and Animal Oppression: Intersectionality Among Species.

[5] Bryson, V. (2003). Feminist Political Theory: An Introduction, (October), 292.

[6] Carrigan, T., Connell, B., \& Lee, J. (1987). The sex role framework and the sociology of masculinity. Weiner, G. and Arnot, M.(1987) Gender Under Scrutiny. New Inquires in Education.

[7] DOREY-STEIN Caroline. (2015). A Brief History: The Three Waves of Feminism.

[8] Eckstein, A. (1984). Orwell,Masculinity and feminist critisism.

[9] Mounce, W. D. (1994). The Morphology of Biblical Greek: A Companion to the Basics of Biblical Greek and Analytical Lexicon to the Greek New Testament, 362. Retrieved from http://books.google.com/books?ei=gDwbUvvzHyXOAWumYDIDA\&id=vbxfAAAAMAAJ\&pgis=1 
[10] Mures Rachel. (2005). feminism, gender, and theology. (the modern theologians, Ed.). oxford:blackwell.

[11] Patai, D. (1984). The Orwell mystique: a study in male ideology. Univ of Massachusetts Press. Retrieved from http://books.google.com/books?hl=en\&lr=\&id= g-gyr7ddFYUC\&pgis=1

[12] POLLERT, A. (1996). GENDER AND CLASS REVISITED: OR, THE POVERTY OF 'PATRIARCHY.' The British Sociological Association, 30(Sociology), 639-659.

[13] Sultana, A. (2012). Patriarchy and Women's Subordination: A Theoretical Analysis. Arts Faculty Journal, 4, 1-18. https://doi.org/10.3329/afj.v4i0.12929

[14] Walby, S. (1990). Theorizing Patriarch. https://doi.org/10.2307/2073659

[15] Wood, J. M. (2013). Patriarchy, Feminism and Mary Daly: a Systematic-Theological Enquiry Into Daly' S Engagement With Gender Issues in Christian Theology. 